New Zealand journal of industrial relations, $1990,15,203-218$

\title{
ARTICLES
}

\section{The labour market, educational reform and economic growth}

\author{
Hugh Lauder," Phillip Brownt and David Hughes*
}

This paper examines the relationship between educational reform, the labour market and economic growth. It argues that recent New Right driven reforms in education, coupled with labour market denegulation, will create a low skilled, low wage economy. It further argues that such an outcome is not inevitable and that it is possible to develop both an education system and labour market structure which can produse a high wage, high technology economy.

\section{Introduction}

Westem societies have undergone major qualitative transformations in the last decade. These are seen as heralding a new era which writers have variously described as postindustrial, post-modern and post-Fordist (Kumar,1991). Nowhere have the effects of these changes been more apparent than in economic and educational systems. The western economic system has been restructured by a series of changes - the oil shock of 1974, the electronic revolution, the internationalisation of the division of labour, the rising competitive force of Pacific rim countries - which have led to fierce international competition and disruption within nation states.

Brown (1990) has argued that western societies are entering a third wave in the sociohistoric development of educational systems. The first wave, in the nineteenth century, was characterised by mass schooling which was intended to confirm rather than transcend existing social divisions. The second wave involved a change in organising principle from an education determined by ascription to one based upon achievement. State bureaucratic education was progressively opened up to all those who had the talent to benefit from it; the key to educational selection lay with the ability and efforts of the child. In the third wave, this organising principle has given way to an education determined by the wealth and wishes of the parents - what Brown calls the ideology of

* Victoria University of Wellington, New Zealand.

$\uparrow$ University of Kent, UK.

\# Univervity of Canterbury. New Zealand. This paper draws on separate and collective work in progress by Phillip Brown, David Hughes and Hugh Lauder. The general thesis that a modernised education system and economy can be created through political struggle is elaborated in Brown and Lauder (1991). The related argument concerning the wastage of talent is developed in Hughes and Lauder (1991). 
parentocracy. The essence of a parentocracy lies in the application of free-market economic principles to education (Lauder, 1987).

\section{The development of free market in education}

Parentocracy has been advocated by the New Right on the grounds that the introduction of market principles into education will create a workforce suitably socialised and skilled to meet the challenges of the new international economic order while also promoting equity and greater freedom of individual choice. The shift in educational policy toward a decentralised market-led system is based on the assumption that, in the social and economic context of the 1990s, bureaucratic forms of education which characterised the second wave are no longer appropriate. It is argued that just as decentralisation and flexibility are the key to successful economic organisations in the new world order so they are the key to educational administration.

Three related theories within the New Right tradition have been used to develop the argument.

\section{A theory of human capital}

The New Right espouses a form of human capital theory (Hughes and Lauder, 1991) which argues that individuals are motivated to:

become capitalists not from the diffusion of the ownership of corporate stock, as folklore would have it but from the acquisition of knowledge and skills that have economic value (Shultz, 1968, p.15).

This theory dresses up in contemporary guise the fundamental New Right assumption that individuals are driven by the rational pursuit of self-interest where the goals are wealth and status. In the modern world, a clear route to these ends is through the acquisition of credentials. This theory enables the New Right to apply the theories of the free-market to education because it argues that human motivation in education is the same as that found in the "free-market". It also creates the theoretical space for the New Right to argue that education is essentially a private good which primarily benefits those who invest in it, and which should be paid for by them.

\section{A theory of educational markets}

Secondly, the New Right argues that the provision of goods and services by the State, including education, is likely to be inefficient because it is not subject to the disciplines of the market. In particular, state provided goods and services are likely to be run in the interests of providers rather than consumers because state monopolies are shielded from the forces of competition.

1. Two consequences follow from this: inequalities are created because parents are denied the opportunity to make educational choices, consequently they become apatheric and hence disinclined to participate in their children's education and, in the absence of competition, standards are likely to decline. This view is derived from the wider state dependency theory developed by the New Right (Lauder, 1987). To support this argument, Niew Right theorists point to the credential success of private schools which are subject to the market forces they believe are necessary for an efficient education system (Treasury, 1987). 
The problem with these 2 theories is that they conflict with the weight of evidence that has been accumulated over the past 30 years. We know, contra human capital theory, that educational aspirations are determined by the sub-cultures of race, gender and class (Hughes and Lauder, 1990). Moreover, it is not private schooling but the social class mix of students within a school which is the crucial factor in school performance. 1 Of course the New Right may accept this evidence and still argue that the creation of an educational market will serve to equalise school mix and boost the educational performance of working class and Maori students.

There are 2 arguments that the New Right can mount. The first, and weaker argument, is to link the notion of choice to parental participation. It can be suggested that where parents have to actively make choices about their childrens' schooling so they will become more interested and involved in their education. The more involved they become, the more they will provide the kind of parental support required for their childrens' educational success. As it stands, the argument is weak because choice can involve a "one-off" decision. In contrast, if participation is to to be educationally effective, it requires active involvement for the duration of a child's education. Moreover, it can be objected that there are active barriers to the involvement of working class and Maori parents in education, in terms of the differences in material and cultural resources between the middle and working class. In Bourdieu's (1977) graphic expression, the middle class exert "symbolic violence" over the working class.

This objection introduces the New Right's second and stronger argument. For, in their terms, the creation of an educational market serves to shift power away from the middle class producers of education to working class and Maori consumers, thereby breaking the monopoly that the middle class has on cultural capital.

However, there are strong objections to be mounted against these arguments. The underlying disparities in material and cultural resources between the educationally successful and unsuccessful are likely to ensure that middle class schools remain middle class. What is likely to happen is that there will be some degree of competition within a segmented market for education; working class schools will compete against each other in one segment while middle class schools will compete against each other in another, but the inherently unequal nature of the competition will ensure that there is no free market in education. The key issue here is that different class, race and gender groups in our society enter the market on vastly different terms. Since this is the case, we can expect the educational market to behave like most other markets. If it does, schools, credentials and the status attached to them are likely to become sharply differentiated, creating elite schools for the rich and a gradation of less prestigious and less "successful" schools beneath them. These less "successful" schools will inevitably provide an inferior education creating the personalities for a low trust, low wage economy. The mechanism by which schools will be differentiated is white middle class flight.

The educational realities of a free market are that rather than generating a more open and competitive education system, the entrepreneurial response from middle class parents, who perceive educational credentials as a way of reducing the social risks of downward social mobility for their children, will be to pay for, or manipulate, access to private or elite state education. In a free market, education will become an even more powerful means for translating material capital into cultural capital. The net effect will be to further polarise the social class mix of schools and hence educational attainment.

Of course, it may be suggested that a modern economy only requires a high level of education for a middle class elite, and that a market-led education system will deliver precisely what the economic conditions of the 1990s demands. But this argument holds

1 A balanced school mix tends to raise the performance of those with low measured ability while doing little to penalise those with high measured ability. As such it is possible to link equality to excellence (Lauder and Hughes, 1990). 
if the only viable capitalist economy is one characterised by low wages and low technology, and therefore a generally low level of educational attainment. In contrast, we shall suggest that a high wage, high technology economy is possible. It will therefore require a generally high level of educational attainment: one which cannot be delivered by a free market for education.

\section{A theory of educational standards and economic productivity}

It is argued that there has been a significant decline in educational standards in state schools, which has contributed to economic decline. The first part of this claim runs into difficulties at both a conceptual and empirical level. As Torrance (1991) puts it:

So definitions of "standards" are changing, and necessarily so. We are becoming more ambitious in what we are trying to achieve. The problem with expanding definitions of standards and achievement in this way is, of course, that they are exceedingly difficult to then measure and report in succinct fashion.

Not surprisingly, if the definition of standards is constantly shifting, it is difficult to make valid comparative claims about a rise or decline in standards. That has not deterred the New Right from repeatedly making the claim, but what evidence there is in either New Zealand or Britain, is either equivocal or points to an increase in standards (Lauder et al.,1988; McPherson and Willms,1987; Wright,1983).

If the claim over standards is problematic, the second proposition in the argument, that educational standards are directly linked to economic success and failure, is even more so. What the precise connection between educational standards - as defined by the New Right - and economic decline is, has not, to our knowledge, been fully explained anywhere; yet the assertion of such a connection has repeatedly been made, most notably and influentially in the American A nation at risk (1983) document.

There are 2 curious features about the New Right discourse on standards. Firstly, having railed against bureaucratic state education and extolled the need for flexibility, New Right educational policies reintroduce the rigidity distinctive of bureaucratic education. The upshot being that, far from providing a superior quality education for all, there is likely to be an overall decline in the kind of educational achievement necessary for the economic conditions of the 1990s. The rigidity attached to the New Right notion of standards is created in 2 ways: on the one hand, standards are defined in terms of standardisation. The selection and packaging of knowledge into arbitrary and discrete subject areas, the equating of educational excellence with excellence in these subjects, the selection and rating of students in terms of their competence in these subjects and the accumulation of qualifications as badges of ability, may well be relevant to the mass production of standardised products, given a stable labour market for bureaucratic competence. But it should be noted how narrow the definition of educational excellence is and how limited the assessment procedures are for rating students according to these standards (Broadfoot, 1989; Khan, 1990; Torrance, 1991).

In part, the emphasis on a "traditional" education reflects the strong conservative strain that runs through New Right thought, but the constraints imposed by this bureaucratic form of assessment also serve a practical purpose in the educational market. The key here lies in the fact that schools and teachers need to provide signals as to their worth to the consumers of education. Inevitably, credentials have become the major signals for secondary schools, while in primary schools benchmark tests have been proposed to give parents an indication of a school's quality. There is, however, widespread agreement that such tests are of little educational value (Nuttall, 1989; 
Torrance, 1991) and will simply serve to deskill teachers and students, as the latter are crammed for the narrow range of skills that will be demanded by the benchmark tests.

The closest we can come to an understanding of how an attachment to a traditional and rigid education of this kind can be causally related to strong economic performance is in terms of the social and moral qualities which coalesce around the New Right notion of standards. For example, Weiner (1982) has attributed Britain's economic decline to an educational culture inimical to industry, while Brown (1990) has suggested that for the New Right, high educational "standards" are associated with the qualities necessary for leadership. As such, the idea is a throwback to the Victorian concept of the "educated man"(sic) who displayed a set of moral as well as cognitive virtues. If Brown is right, the concept of "standards" is more revealing of the social order envisaged by the New Right than illuminative of the education-economy relationship. 2

This apparent "leap of faith" between the coupling of educational and economic decline should make us wary of the claim that a market driven education system can contribute to the promotion of economic growth. Yet those who have sought to critique the move to parentocracy in education have, by and large, failed to address the question of the relationship of education to economic growth (Lauder, Hughes and Brown, 1990). This has meant that the further questions of equity and human freedom have largely been fought on the New Right terrain of economic efficiency.

So far we have argued that, in general, the application of New Right theory to education is likely to lead to a rigid low quality education for the majority. We now want to examine, as a case study, one aspect of this policy in the specific context of New Zealand - namely the recently introduced user-pays' policy for tertiary education. In doing so we shall develop an alternative way of looking at the relationship of education to economic performance through the notion of the wastage of talent. This will lead us into a discussion of New Right labour market policies and skill training. Here we shall argue that the consequence of the introduction of New Right policies in education and the labour market will be to create a low wage, low technology economy. In other words, an economy which is unable to compete internationally and which is likely to increase inequality of opportunity and reduce human freedom. However, there are alternative strategies available which can produce a high wage, high technology economy. Such an economy will require dramatic changes in the structure of economic production and the nature of state welfare and educational provision; changes which are antithetical to New Right inspired policies. In what follows, we want to sketch out the framework for this alternative.

\section{The wastage of talent}

In developing this framework we want to draw attention to an important but neglected tradition in the sociology of education which has linked education to the economy through the notion of the wastage of talent. This tradition, which extends back as far as the twenties (Baron et al., 1981), is rooted in the Fabian notion of "capacity catching" -

2 Historical and sociological analysis have shown that the maintenance of the traditional curriculum has more to do with supporting class privilege than promoting economic efficiency. The idea that the traditional curriculum is in the interests of capitalist efficiency is an error shared by New Right and neo-Marxist correspondence theorists. See Muller, Ringer and Simon (1987); Lauder (1988); Hickox and Moore (1991). What the distinction between class and economic interests points out is that there is a clear contradiction in market societies between the privatisation of knowledge and economic efficiency. 
the idea that there is a limited pool of talent which needs to be recruited to the executive positions in society, irrespective of the social origins of those so endowed.

This argument was used to greatest effect to advance the principles of educational organisation associated with the second wave of educational development, particularly in Britain where Halsey and Floud (1961) advocated the promotion of educational opportunities through comprehensive schools. Since then this tradition has been neglected, largely because it was associated with the failure of the liberal reforms of the $1960 \mathrm{~s}$ in Britain to secure equality of opportunity. Now the notion of wastage of talent assumes importance in the light of the education required for the promotion of a modernised, high technology economy. Its potential lies in its ability to draw far more intelligible links between education and the economy than New Right theory has been able to do, while at the same time drawing attention to the power structures of race, gender and class - ignored by human capital theory - which impede the promotion of talent (Brosnan,1987; Lauder and Hughes, 1990; ONeill,1990).

Halsey and Floud made the key connection between the wastage of talent and economic growth when they argued that:

Education is a crucial type of investment for the exploitation of modern technology. This fact underlies recent educational development in all industrial societies ... education attains unprecedented economic importance as a source of technological innovation (1961, pp.1-2).

However, because the notion of the wastage of talent is rooted in the assumptions underlying the second wave of educational development, their concept of talent and the opportunities for its exercise in the service of technological innovation is circumscribed. An implicit assumption underlying the traditional use of the notion is that intelligence is a property of individuals, and that there is only a limited, if somewhat randomly distributed, pool of highly intelligent individuals. ${ }^{3}$ The assumption fitted well with both the bureaucratic nature of education and the economy which characterised the period of the second wave. It can be argued that western education systems were primarily constructed to select and promote the elite of "high ability" students.for the elite positions within the structures of bureaucratic work (Brown and Lauder, 1991). The key point being that bureaucratic work is organised for an elite to make fundamental decisions about technical innovation and policy development - a form of organisation which was consistent with the economic conditions of the time which were characterised by low technological innovation and mass marketed fixed product lines.

The combined consequences of a bureaucratic education system which ruthlessly culled "the untalented", and a system of work in which the majority exercised more intellect and skill in driving to work than they did at work (Blackburn and Mann, 1979), has created a massive wastage of talent. In an attempt to understand the dimensions of the problem, we calculated the wastage of talent in New Zealand prior to the recent policies introduced by the Labour Government (Hughes and Lauder, 1991). We found that, when measures of scholastic ability had been taken into account, students from white collar clerical and blue collar backgrounds missed out on 299 scholarships, 4398 Bursaries, 2091 Higher School Certificates and 805 University Entrances. Even if these figures are discounted at 10 or 20 percent, they are alarming, especially since our model does not account for the specific aspects of sexism and racism which may deter the development of talent.

We then went on to calculate the precise numbers of students from these backgrounds who would have gone to university had they followed the pattern of students from

3 The psychometric tradition has given us the highly questionable legacy of these assumptions. For a critique of them see Evans and Waites (1981) and for an alternative view of intelligence as a collective phenomena see Brown and Lauder (1991). 
professional and managerial backgrounds. Lauder, Hughes and Taberner (1985) found that around 70 percent of students from professional and managerial backgrounds with University Entrance went to university. If we assume that under a more egalitarian system, 70 percent of students from white collar clerical and blue collar backgrounds who missed out on University Entrance or higher qualifications would have gone to university, then an extra 5315 would have gone to university in 1983. If we assume that, on average, students entering university stay for 3 years, then approximately 16,000 extra students would have been in the university system by 1985 . This means that if all students in New Zealand were able to fulfil their potential to the same level as students from professional and managerial backgrounds, the country would need an extra 2 medium-sized universities.

\section{The policy implications of human capital theory and the wastage of talent}

This is an estimate of the wastage of talent prior to the introduction of recent policies such as the raising of fees for university students. The introduction of this policy is interesting, from a theoretical point of view because it appears quite consistent with human capital theory. On the one hand, the Labour Government acknowledged that there is a problem in encouraging students from blue collar backgrounds to take tertiary education and it therefore signalled its intention of introducing a youth allowance scheme to enable these students to stay on at school. On the other hand, it has increased fees to tertiary institutions on the human capital assumption that once blue collar students have reached the seventh form they will see the advantages in monetary and status rewards that a tertiary, particularly university, education, can offer. In other words, the rational pursuit of self interest can overcome the financial barriers posed by the introduction of fees.

In this view, the only factor which has prevented blue collar workers from staying on at school is income. It preserves the fiction that the material conditions of people's lives do not translate into specific class cultural assumptions about the nature of the world, and particularly education.

However, in justifying this policy the Labour Government produced 2 conflicting accounts. In the first instance it argued that it wanted to see more students in tertiary education because a highly skilled workforce is desirable. The fees were being levied in order to increase the number of possible places at tertiary institutions, as a result of the increased numbers who would be encouraged to enrol as a result of the introduction of student allowances, and a pervasive propaganda campaign. Latterly, it seems, the Labour Government adopted a market rationale for the introduction of fees by suggesting that the fees will regulate demand for higher education. ${ }^{4}$ In doing so it achieves the New Right aim of reducing state expenditure, while seeking refuge in the New Right shibboleth that the choices individuals will make with respect to education - assumed to be best for them - will also be best for the economy (Hughes and Lauder, 1991).

Two issues arise out of this "user-pays" policy and its conflicting rationales. The first relates to the issue of whether increased fees, or indeed any financial barrier such as loans, will deter blue collar students from attending tertiary institutions, particularly university. In our view, this issue is quickly settled, given the evidence we presented in the previous section. Working class students have traditionally left school due to both a lack of money and the cultural assumptions of their class as regards education (Brown, 1987). Human capital theory is simply false when it comes to the issue of human motivation. The prediction is born out by the work of Power and Robertson (1987) in

4 This alternative market view was articulated by Phil Goff, the Labour Minister of Education, on Morning Report, 13 February 1990. 
Australia, who found that working class students were highly sensitive to increased barriers to entry to tertiary institutions.

It could be argued that the Labour Government's propaganda campaign to keep students at school, and the promise of financial support for them, has produced a fundamental change in the educational assumptions of the working class, as evidenced by the increasing numbers of students now staying on at school. We are sceptical about this argument; the historically constructed "wisdom" of the working class 5 with respect to education, is unlikely to be changed so easily. This view is born out by overseas research (Gambetta,1987; Raffe and Willms, 1989) which suggests that, for many working class students, school is simply used as a "parking lot" until they are too old for school or there is an improvement in their labour market prospects.

There is a further issue. Many students must be asking what the point of further education and training is, when unemployment keeps rising. This question points to a deep contradiction in the Labour Government's policy with respect to education, training and the labour market. It has, largely, pursued New Right policies which have not only created unprecedented levels of youth unemployment but which, we shall suggest, are designed to create a low wage, low technology economy. If this is correct, school students have every reason to ask why they should upgrade their education and skills.

The second related issue concerns the connection between education and economic growth. Do we need greater numbers of highly skilled workers as the Labour Government initially suggested or should the supply of highly educated labour be restricted, as is likely with the increase in fees?

\section{The relationship of education to economic growth: notes toward an alternative theory}

The degree to which the wastage of talent is an economic problem turns on the question of the kind of economy to be constructed. Clearly, under bureaucratic forms of work, high levels of wastage of talent could be tolerated - precisely because the conception and initiation of innovation and policy rested in the hands of an elite, while for the majority of workers tasks were fragmented into a set of routine procedures. Under stable economic conditions bureaucracy provided a powerful technology for producing a range of predictable outcomes. However, in the face of the new era of competition many now consider the bureaucratic organisation of work is obsolete. As Bennis (1968) puts it:

The pyramid structure of bureaucracy, where power is concentrated at the top, seems the perfect way to "run a railroad". And for the routine tasks of the nineteenth and early twentieth century centuries bureaucracy was ... a suitable arrangement. However, rather than a placid and predictable environment, what predominates to-day is a dynamic and uncertain one (p.262).

Given the demise of economies based on bureaucratic forms of work, we are currently faced with 3 broad choices which have quite different implications for the utilisation of talent, education and training. We can take the path of a rationalised, high technology economy which simply improves bureaucratic forms of mass production by replacing

5 For an elaboration of this concept, see Hughes and Lauder (1990). The "wisdom" of either the working class or ruling class, as regards education, comprises a deep structured set of rules of thumb, symbols and "folk wisdom". Together they typically generate the educational decisions members of the respective classes make. This theory about how educational decisions are made, stands in contrast to the theory of human capital. 
individuals with machines, with the net result of increased unemployment and a wastage of talent.

We can take the path of a low wage, low technology economy in which talent can also be squandered, since low wage work is typically repetitious and boring. The alternative to these possibilities is to take the path of a modernised economy of diversified quality production in which technological capability is harnessed to human creativity. It is only with this alternative that there is the potential for eliminating the wastage of talent.

A modernised, high quality production economy recognises that, in an intensely competitive market, advantage is gained by decentralising the capabilities of decisionmaking and innovation. This enables more rapid responses to be made to market demands, and it enables firms to gain a competitive advantage through human creativity. The drive in a modernised economy is to upskill workers, in contrast to a bureaucratic economy in which the drive is to fragment tasks and so deskill workers. The differences between a bureaucratic and modernised economy, in terms of organisational structure and labour characteristics, are summarised in the table below taken from Brown and Lauder (1991).

Bureaucratic economic organisation

Protected national markets

Mass production of standardised products

Hierarchical organisation

Compete by full capacity utilisation and cost-cutting

\section{Modernised economic organisation}

\section{Global competition}

Flexible production systems/small batch/niche markets

Flatter, flexible organisational structures

Compete by innovation

diversification, sub-contracting

\section{Labour characteristics}

Fragmented and standardised work tasks

Low trust/low discretion

Little on the job training

Little formal education required for most jobs

Small managerial and professional elite
Flexible specialisation/multi-skilled workers

High trust/high discretion

Regular on the job training

Greater demand for "knowledgeable" workers

Growing managerial and professional class

The differences between organisational structures and labour characteristics are clear in their use of human creativity. A modernised economy has the progressive potential of 
providing human beings with satisfying work. 6 The crucial issue turns on how decisions are made about the economic strategies to be taken. In our view, this is fundamentally a question about the balance of power in any specific society. During the period of economic crisis and restructuring that western economies are undergoing, much has been made of the notion of efficiency, especially by the advocates of New Right, driven market policies. But there is no single (technicist) route to economic efficiency, rather, we need to see "efficiency" as intimately related to questions of power and risk (Crozier, 1964). We can hypothesise that those who make the fundamental decisions about our economic destinies will choose the strategy which minimises their risk of losing power. In countries where trade union movements have been traditionally weak, or successfully attacked by the New Right, free market solutions have been imposed, with the outcome that those countries are on course for low wage, low technology, economies - as we shall demonstrate. However, a number of Scandanavian theorists, such as Korpi (1983), Esping-Andersen (1985a, 1985b) and Therborn (1985), have shown that where societies have strong trade union movements linked to left-wing parliamentary parties, corporatist strategies in which power has been shared between employers, trade unions and the state, have been developed. The result has been that these societies have adopted strategies leading to high technology, quality production economies.

In contrast, free market policies are likely to lead to the stripping of industrial bases through the use of high interest, high exchange rate, high unemployment policy instruments (Jessop et al., 1990). The consequence of these policies is to produce conditions inimical to the creation of a modernised economy, precisely because a high interest rate, high exchange rate regime creates a disincentive to invest in new technology, while high unemployment has the effect of reducing wages. The net effect is to produce a low wage, low technology economy. A similar effect can be predicted for New Right policies in the areas of training and labour market flexibility. The 2 areas are linked. One of the persistent myths disseminated by the New Right has been that a major reason for New Zealand's economic crisis has been a shortage of skills. The problem has been seen almost exclusively as a problem for the education system. Such a view suits an ideology which rejects any notion of corporate planning in the area of training, and which promotes the myth that the deregulation of the labour market will lead to the development of a high technology, high wage society.

\section{Skill and labour market flexibility in a modernised economy}

\section{Linking education to the economy: skills}

The New Right argues against state intervention in the economy, especially in the labour market. Typically, it is argued that education and skill training should be left to the State acting as supply side agents. This leaves the labour market itself unencumbered by any state demand or strictures on employers to engage in training beyond what is considered necessary for profitability.

However, in an important article on skill training, Streeck (1989) has argued that under a free labour contract system, which gives workers the right to move from one firm to another, skills become a collective good in the eyes of employers. This is because the

6 While a modernised economy has progressive potential, it also poses problems, since the typical structure of a firm in such an economy is one which divides labour into core and periphery workers. There is the potential for the latter to become the marginalised workers of an underclass. We are not suggesting that a modernised capitalist economy should replace communism as a utopia, merely that it has progressive potential that is worth struggling for. 
rewards of training individuals can easily be "socialised" by the expedient of trained workers moving to another job, while the costs of the training remain with the individual employer. Since employers face a clear risk in losing their investment if they provide an extensive training programme, they are unlikely to do so. Streeck argues that, as a result, western economies are likely to face a chronic skills shortage unless the State intervenes to ensure adequate training occurs.

Moreover, unless there is state intervention, employers will reduce the training programmes they do have in times of intense competition and/or recession. Streeck notes that when the crisis of the western motor industry broke out in the 1970 s, all major western producing countries, except Germany, reduced their apprenticeship programmes. In Germany, government and trade union pressure ensured that the apprenticeship programme was extended. Two consequences followed: the system helped to alleviate youth unemployment, and it contributed to the technical and economic advantage enjoyed by the German motor industry during the period of restructuring and after.

Not surprisingly, Streeck argues that the German system, where enterprises have also become places of learning, provides the best way of ensuring an adequate supply of relevant skills. There are 2 components to this form of training. Firstly, the enterprise appoints staff with the specific responsibility of training apprentices. Secondly, vocational schools are necessary to supplement skill training at work through sandwich and block courses. In this way, specific skills learnt at work can be generalised, through initiation, into a wider body of craft knowledge. Of course, one consequence of such a system is that the deregulated firm, the cornerstone of New Right doctrine, is unacceptable. Enterprises will have to be drafted and mandated by regulating agencies to produce skill training programmes.

What kind of skill training is desirable? Again the German method of training is instructive. Here knowledge and capabilities are acquired in 2 or more areas, through systematic rotation through skill "areas" during training. According to Lane (1988), this system of training has facilitated a shift to modernised forms of production because it has enabled employers to implement a strategy of "responsible autonomy". This notion:

refers to a strategy which allows workers reasonable scope in utilising their skills and trusting them to use them responsibly ... This form of work organisation implies a structure of control which minimises task control ... The ideology is based on the idea of a professional community in which superiors are respected as "experts" rather than as punitive controllers and a common task orientation dwells on unity of purpose and de-emphasises hierarchical divisions (p.144).

The economic pay off is that "responsible autonomy" allows a flexible and quick response to market conditions, the characteristics which lie at the heart of a modernised economy. Of course, a corporate approach to training of the kind Streeck advocates would be unwelcome to the New Right. But, by itself, even adequate levels of training are not sufficient to promote a strong economy. Appropriate labour market conditions have to exist which are also an anathema to the New Right. To see why this is so, we need to look more closely at the notion of labour market flexibility.

\section{Labour market flexibility}

Rhetoric about labour market flexibility has been much in the air recently. One notion of flexibility, the idea of replacing national bargaining structures with plant bargaining, is quite consistent with the theory and practice of the New Right, for whom the most efficient unit of production is the unregulated firm. It has the knowledge of local conditions and its own productive potential to best make an assessment of what 
workers should be paid. On the other side of the coin, national bargaining structures strengthen trade unions which are seen as distorting the market because they create labour monopolies. In doing so, they artificially bid up the price of labour that firms have to pay, with the consequence that firms are rendered inefficient because they have to sustain higher than necessary costs. In practice, plant bargaining breaks up the solidarity of wage labour and opens the way for greater exploitation of the workforce, precisely because, in the absence of the potential for collective action, employers can drive wages down.

In "freeing up the market" in this way, New Right economists argue that unemployment will be cleared as entrepreneurs discover that lower wage costs and selling prices enable them to market more goods and services. Moreover, cheaper workers make the replacement of labour by technology less attractive. However, it can be argued that this notion of flexibility is a recipe for a low technology low wage economy in which low wage, low technology forms of production are likely to prevail because employers have no incentive to innovate. As Brosnan and Wilkinson (1989) argue:

Relying on cheap labour allows inefficient producers and obsolete technologies to survive and compete. But the firms involved become caught in a low productivity trap from which they have little incentive to escape. When these firms are subjected to competition from more efficient competitors, improved technology and products, their only hope of survival is to reduce wages further (p.54).

They argue that in periods of high unemployment it is easier for firms to drive down wages, providing the basis for the competitive survival of inefficient producers with the result that:

\begin{abstract}
The consequent intensification of competition adds to the increased uncertainty and risk induced by economic depression, further reduces the incentive to invest and innovate, and builds up reliance on low pay and casualised employment forms as the only means of survival ... The attention of many firms is increasingly concentrated on the very short-term future, to the neglect of longterm investment, innovation and the development of new and improved products (p.54).
\end{abstract}

Significantly, they also go on to argue that it is the bargaining structure which helps to keep wage setting out of the downward spiral of inter-firm competition. In essence, then, the New Right device of using the combination of unemployment and market deregulation as a weapon to lower wages, provides the route to a third-world economy.

However, there are 3 further senses of labour market flexibility which are consistent with a high wage high technology economy. The German system of training, for polyvalent skills which produces the kind of flexibility necessary for modernised production, has already been referred to. It should be emphasised that in Germany this kind of flexibility is developed in conjunction with national bargaining structures, thereby maintaining the incentive for new technology to be introduced into the economy.

Another sense of labour market flexibility can be found in national programmes of skill retraining and regional industrial reconstruction such as those found in Sweden (Standing, 1988). While New Right dominated countries, like New Zealand and Britain, leave large numbers languishing on the dole queues, Sweden has introduced a system of industrial relocation and retraining for the unemployed with considerable success. As Standing notes:

Since the 1970's, the [Swedish] economy has had to undergo a major structural adjustment, involving considerable industrial and regional restructuring of employment. It has achieved this without a period of mass unemployment, although the rate briefly touched 4 percent. Perhaps indicative of how radical the transformation of the economy has been, is the fact that whereas in the 
early 1970's Sweden had the second largest shipbuilding industry in the world, by the mid-1980s it had moved out of shipbuilding altogether, having trained, retrained and relocated the substantial workforce, without the prolonged unemployment associated with shipyard closures elsewhere (p.94).

The point here is that the State not only provides strong incentives for retraining, it also plays an important role in relocating industry to where unemployment exists. In this sense, labour market flexibility involves extensive state intervention at the level of individual workers and industrial relocation.

There are, then, at least 3 forms of state intervention necessary to provide the framework and incentives for a modernised form of production, flexible training, industrial relocation and national bargaining structures. Major elements of this framework are utilised by the most successful western economies yet, they fly in the face of New Right theory which has exerted a decisive influence on policy-making in New Zealand.

\section{Conclusion}

In this paper we have attempted to develop a framework which provides a general critique of New Right policies in education and the economy and which signposts an alternative education and economic strategy. The general tenor of our argument has been to claim that New Right policies in education and the labour market are likely to produce a well educated elite of managers, and a labour force socialised for a low trust, low paid, low skill economy. What is required for a modernised economy is a high standard of educational attainment for all, in which talent is not wasted, and in which the education system prepares people to make fundamental and innovative decisions at work (Lauder and Brown, 1991)

It is the case that New Right policy has not been applied unvarnished in either education or the labour market - yet. We looked, therefore, at the introduction of userpays policies in tertiary education as a case study of one New Right influenced policy. On the basis of our analysis of the wastage of talent, we argued that user-pays policies are likely to act as a barrier to the development of talent. In our view, the question of how talent is utilised in New Zealand is decisive for the country's economic future. To the extent that the New Right is allowed to dominate the education-economy agenda, the future looks very much like a return to the privilege and deprivation out of which the first wave of educational reform emerged. 7

7 It should be pointed out that the educational reforms in New Zealand have been implemented with almost no serious discussion of the relationship of education to economic productivity. The only attempt to engage with the issues was made by the Treasury (1987) but their efforts were weak. See Lauder et al. (1988) and Boston et al. (1988) for a critique of the Treasury. Notwithstanding the Treasury's efforts, there has been no discussion of the different impacts of centralised and decentralised educational administrations on the economy. Since some of the most successful modernised economies, e.g. Sweden and Germany, have highly centralised education systems, some debate on this issue might have been expected. Furthermore, there was no attempt to assess the impact of the creation of a limited educational market, such as that created by Tomorrow's Schools (1988). A series of pilot studies were required to evaluate the effects of the Tomorrow's Schools reforms before they were applied wholesale. In all, the recent educational reforms stand as an object lesson in how not to develop and apply educational policy. 


\section{References}

Baron, S. et al. (1981) Unpopular education. London, Hutchinson.

Bennis, W. (1968) The coming death of bureaucracy. In A. Athos and R. Coffey (ed) Behaviour in organisations. New Jersey, Prentice Hall.

Blackburn, R., and Mann, M. (1979) The working class in the labour market. London, Macmillan.

Boston, J., Haig, B., and Lauder, H. (1988) The third wave: A critique of the New Zealand Treasury's report on education, Part II. New Zealand journal of educational studies. 23(2): 115-143.

Bourdieu, P. and Passeron, J-C. (1977) Reproduction in education, society and culture. London, Sage.

Broadfoot, P. (1989) The significance of contemporary contradiction in educational assessment policies in England and Wales. Education Department, University of Bristol, mimeo.

Brosnan, P. (1987) Maori occupational segregation. Australian and New Zealand journal of sociology. 23(1): 89-103.

Brosnan, P. and Wilkinson, F. (1989) Low pay and the minimum wage. Wellington, New Zealand Institute of Industrial Relations Research.

Brown, P. (1987) Schooling ordinary kids. London, Tavistock.

Brown, P. (1990) The "Third Wave": Education and the ideology of parentocracy. British journal of the sociology of education. 11(1): 65-85.

Brown, P. and Lauder, H. (1991) Education, economy and society: A new agenda. In P. Brown and H. Lauder (ed) Education for economic survival. London, Routledge.

Crozier, M. (1964) The bureaucratic phenomenon. Chicago, Chicago University Press.

Department of Education (1988) Tomorrows schools. Wellington.

Esping-Andersen, G. (1985a) Politics against markets. Princeton, Princeton University Press,

Esping-Andersen, G. (1985b) Power and distributional regimes. Politics and society. 14(2): 223-56.

Evans, B. and Waites, B. (1981) IQ and mental testing. London, Macmillan.

Gambetta, D. (1987) Were they pushed or did they jump? Cambridge, Cambridge University Press.

Halsey, A. et al. (ed) (1961) Education, economy and society. New York, Free Press. 
Hickox, M. and Moore, R. (1991) Education and post-Fordism: A new correspondence? In P. Brown and H. Lauder (ed) Education for economic survival. London, Routledge.

Hughes, D. and Lauder, H. (1990) Public examinations and the structuring of inequality. In H. Lauder and C. Wylie (ed) Towards successful schooling. Lewes, Falmer Press.

Hughes, D. and Lauder, H. (1991) Human capital theory and the wastage of talent in New Zealand. New Zealand journal of educational studies (forthcoming).

Jessop, B., Bonnett, K. and Bromley, S. (1990) Farewell to Thatcherism?, neo-liberalism and "new times". New Left review. 179 (January/February): 81-102.

Kahn, G. (1990) The politics of curriculum innovation. In H. Lauder and C. Wylie (ed) Towards successful schooling. Lewes, Falmer Press.

Korpi, W. (1983) The democratic class struggle. London, Routledge and Kegan Paul.

Kumar, K. (1991) From "post-industrial" to "post-modern" society: New theories of industrial society. In P. Brown and H. Lauder (ed) Education for economic survival. London, Routledge.

Lane, K. (1988) Industrial change in Europe: The pursuit of flexible specialisation in Britain and West Germany. Work, employment and society. 2(2): 141-168.

Lauder, H. (1987) The New Right and educational policy in New Zealand. New Zealand Journal of educational studies. 22(1): 3-23.

Lauder, H. (1988) Traditions of socialism and educational policy. In H. Lauder and P. Brown (ed) Education in search of a future. Lewes, Falmer Press.

Lauder, H. and Hughes, D. (1990) Social inequalities and differences in school outcomes. New Zealand journal of educational studies. 25(1): 37-60.

Lauder, H. et al. (1988) The third wave: A critique of the New Zealand Treasury's Report on Education. New Zealand journal of educational studies. 23(1): 15-33.

Lauder, H., Hughes, D. and Brown, P. (1990) Tomorrow's economy, tomorrow's education. Proceedings of the Special Seminar on Educational Policy, Massey University.

Lauder, H., Hughes, D. and Taberner, S. (1985) Education, class and inequality in New Zealand: A preliminary report. Delta. 36(August): 31-37.

McPherson, A. and Willms, D. (1987) Equalisation and improvement: Some effects of comprehensive organisation in Scotland. Sociology. 21(4): 509-39.

Muller, D. et al. (ed) (1987) The rise of the modern educational system. Cambridge, Cambridge University Press.

National Commission on Excellence in Education (1983) A nation at risk: The imperative for educational reform. Washington DC, United States Government Printing Office.

Nuttall, D. (1989) National assessment! Compacency or misinterpretation? In D. Lawton (ed) The Education Reform Act; choice and control. London, Hodder and Stoughton. 
O'Neill, A-M. (1990) Gender and education: Structural inequality for women. In J. Codd et al. (ed) Political issues in New Zealand Education. Palmerston North, Dunmore Press.

Power, C. and Robertson, F. (1987) Factors influencing participation in higher education in Australia. Paper presented to the NZARE/AARE Conference, Christchurch.

Raffe, D. and Willms, D. (1989) Schooling the discouraged worker: Local labour market effects on educational participation. Sociology. 4: 559-581.

Shultz, T. (1968) Investment in human capital. In M. Blaug (ed) Economics of education. Harmondsworth, Penguin.

Standing, G. (1988) Training, flexibility and Swedish full employment. Oxford review of economic policy. 4(3): 94-107.

Streeck, W. (1989) Skills and the limits of neo-liberalism: The enterprise of the future as a place of learning. Work, employment and society. 3(1): 89-104.

Therborn, G. (1985) Why are some people more unemployed than others? London, Verso.

Torrance, H. (1991) Educational assessment and educational standards. In P. Brown and H. Lauder (ed) Education for economic survival. London, Routledge.

Treasury (1987) Government management vol II: Education. Wellington.

Weiner, M. (1981) English culture and the decline of the national spirit, 1850-1980. Cambridge, Cambridge University Press.

Wright, N. (1983) Standards and the Black Papers. In B. Cosin and M. Hales (ed) Education, policy and society. London, Open University Press. 